Article

\title{
Immobilization of Eversa Lipase on Octyl Agarose Beads and Preliminary Characterization of Stability and Activity Features
}

\author{
Sara Arana-Peña ${ }^{\dagger}$, Yuliya Lokha ${ }^{\dagger}$ and Roberto Fernández-Lafuente $*$ (D) \\ Departamento de Biocatálisis, Instituto de Catálisis-CSIC, Campus UAM-CSIC, 28049 Madrid, Spain; \\ sara_arana@hotmail.com (S.A.-P.); yuliyalokha@gmail.com (Y.L.) \\ * Correspondence: rfl@icp.csic.es \\ + Both authors have evenly contributed to this paper.
}

Received: 11 October 2018; Accepted: 31 October 2018; Published: 2 November 2018

check for updates

\begin{abstract}
Eversa is an enzyme recently launched by Novozymes to be used in a free form as biocatalyst in biodiesel production. This paper shows for first time the immobilization of Eversa (a commercial lipase) on octyl and aminated agarose beads and the comparison of the enzyme properties to those of the most used lipase, the isoform B from Candida antarctica (CALB) immobilized on octyl agarose beads. Immobilization on octyl and aminated supports of Eversa has not had a significant effect on enzyme activity versus p-nitrophenyl butyrate (pNPB) under standard conditions ( $\mathrm{pH} 7$ ), but immobilization on octyl agarose beads greatly enhanced the stability of the enzyme under all studied conditions, much more than immobilization on aminated support. Octyl-Eversa was much more stable than octyl-CALB at $\mathrm{pH} 9$, but it was less stable at $\mathrm{pH} 5$. In the presence of $90 \%$ acetonitrile or dioxane, octyl-Eversa maintained the activity (even increased the activity) after 45 days of incubation in a similar way to octyl-CALB, but in $90 \%$ of methanol, results are much worse, and octyl-CALB became much more stable than Eversa. Coating with PEI has not a clear effect on octyl-Eversa stability, although it affected enzyme specificity and activity response to the changes in the $\mathrm{pH}$. Eversa immobilized octyl supports was more active than CALB versus triacetin or $\mathrm{pNPB}$, but much less active versus methyl mandelate esters. On the other hand, Eversa specificity and response to changes in the medium were greatly modulated by the immobilization protocol or by the coating of the immobilized enzyme with PEI. Thus, Eversa may be a promising biocatalyst for many processes different to the biodiesel production and its properties may be greatly improved following a suitable immobilization protocol, and in some cases is more stable and active than CALB.
\end{abstract}

Keywords: Eversa; interfacial activation; lipase immobilization; enzyme stabilization; enzyme modulation

\section{Introduction}

Lipases are very interesting enzymes in biocatalysis due to their broad substrate specificity, their selectivity and high stability, combined in many instances with a very high enantio or regio selectivity and specificity [1-10]. Moreover, they can perform their function in a wide diversity of reaction media [11-13].

One of the hottest topics in lipase application is the production of biodiesel [14-16]. Although, currently, chemical catalysis is used in most factories, the use of lipases may have interest to save energy, reduce contaminants and side-products and also to prevent pretreatment of the oils (as acid oils are not compatible with alkali catalysis) $[17,18]$.

Lipases catalytic mechanism is quite peculiar, as the enzyme is in a conformational equilibrium [19-21]. In the closed form, a polypeptide (named lid) blocks the active center, making the 
enzyme inactive in many cases. In the open form, the lid is shifted and exposes to the medium a large hydrophobic pocket containing the active center. This pocket may become adsorbed and stabilized to any hydrophobic surface, like drops of oils (the so-called interfacial activation) [21,22], but also to hydrophobic proteins [23,24], another open form of a lipase [25,26] or a hydrophobic support [27].

Thus, hydrophobic supports can promote the one step immobilization/stabilization/purification and hyperactivation of lipases [28], because the open form of the lipase becomes fixed after immobilization [29]. Moreover, the lipase is in monomeric form [25-29], ensuring that all lipases have a similar conformation and state.

As a result of the interest for new lipases, the most important enzyme producing companies have developed an intense search for lipases directed to some specific uses. Among them, Novozymes has launched a lipase preparation called Eversa. In 2014, the enzyme was announced as "Novozymes Eversa ${ }^{\circledR}$, the first commercially available enzymatic solution to make biodiesel from waste oils" [30]. Since then, the enzyme has been mainly used in biodiesel production [31-38]. In all these papers, the enzyme has been used in free form as recommended by the supplier. Thus, there is not a proper characterization of the enzyme in terms of stability, activity, etc. in other reactions. An exception to the use of free enzyme is the very recent paper from Remonatto et al. that used immobilized Eversa, although again without a characterization of the immobilized enzyme properties and focused on biodiesel production [39].

Even though this enzyme may be used in free form, their immobilization may enhance many properties. A proper immobilization may improve enzyme stability, activity, selectivity, or specificity, resistance to inhibitors or chemicals, even purity [40-47]. This improvement has already been shown in biodiesel production using different hydrophobic supports [48-50].

On the other hand, following the concept of combilipase, it is difficult to believe that a single lipase may be the ideal one for all oils, and for each of the possible substrates contained in a heterofunctional product like a vegetal oil [51,52]. Therefore, it seems sensitive to evaluate in a more global form the properties of this new lipase.

Thus, in this paper we have intended to immobilize and to perform a first characterization of some features of Eversa (e.g., stability and activity at different $\mathrm{pH}$ values versus different substrates, stability in the presence of different organic solvents). To this goal, the enzyme has been immobilized on octyl agarose, via interfacial activation as described above [29]. The main problem of this immobilization protocol is the possibility of enzyme desorption during operation. This may occur at high temperature or in the presence of high concentrations of organic solvents [53], also if the substrate or the product has detergent properties [54-56]. To avoid enzyme release, the employment of heterofunctional supports (having acyl groups plus some chemically reactive groups) has proved to be a valid solution $[53,57,58]$. Another simpler alternative is the chemical or physical crosslinking of the enzyme molecules, which reduces the risks of enzyme release from the support [59]. The coating of immobilized lipases with PEI is one of the most used proposals [60-62], as this reagent may have many positive impacts in enzyme properties. [63]. Moreover, lipases coated with PEI have been proposed as a first step in the building of coimmobilized enzymes enabling the reuse of the least stable one [64,65]. Finally, this polymer has been also proposed to coimmobilize enzymes and cofactors [66].

The new Eversa enzyme has been compared with the lipase B from Candida antarctica (CALB), perhaps the most popular lipase in biocatalysis, immobilized also in octyl agarose $[67,68]$.

Thus, the main objective of the current paper is to show a first evaluation of the properties of Eversa, immobilized on octyl agarose beads and treated with PEI, under different conditions, which may be expected that will have a likely impressive impact in the next future due to some of their properties [31-39]. Eversa has been also ionically exchanged in aminated agarose for comparison with octyl agarose.

To this goal, Eversa immobilized via interfacial activation or ion exchange has been compared to CALB immobilized via interfacial in terms of activity versus different substrates and under different conditions as well as their stabilities in different media and conditions, to analyze the properties of the 
new enzyme compared to CALB and the effects of the immobilization of the enzyme, even though the manufacturer claims that this is an enzyme to be used in free form.

\section{Results}

\subsection{Immobilization of $C A L B$ and Eversa}

Figure 1 shows the immobilization courses of CALB and Eversa on octyl agarose beads and in the case of Eversa, on monoaminoethyl-N-ethyl-agarose (MANAE) agarose beads. CALB slightly decreased its activity after immobilization on octyl agarose, while the activity of Eversa remained almost intact, being immobilization marginally more rapid, using both enzymes immobilization yield is over $95 \%$. Eversa on MANAE also maintains full activity, but immobilization yield is around $80 \%$.

(a)

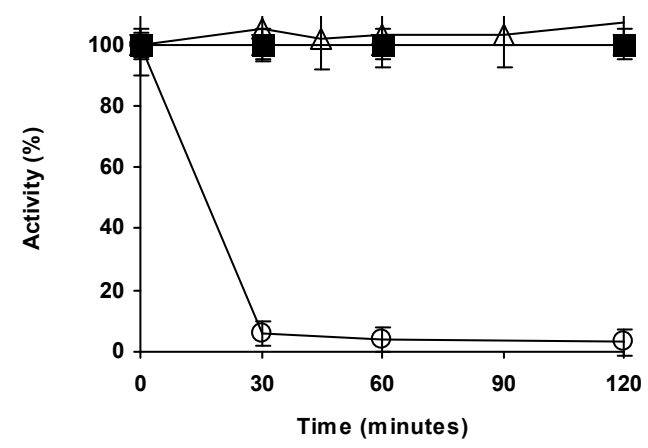

(b)

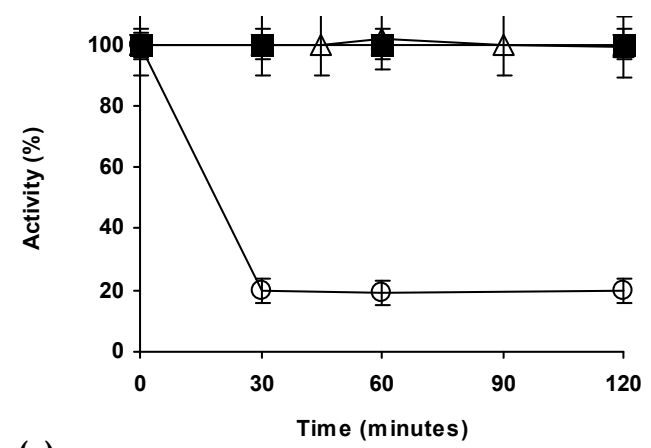

(c)

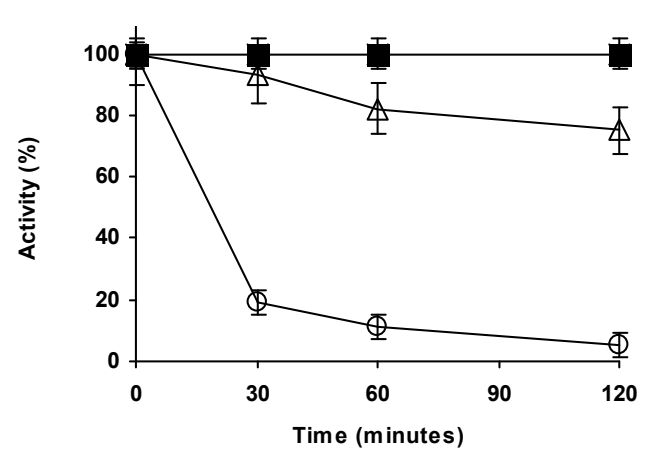

Figure 1. Immobilization courses of Eversa on octyl (a) or MANAE (b) agarose beads and CALB on octyl (c) agarose beads. Experiments were performed as described in methods section. Solid squares: reference, circles: supernatant; empty triangles: suspension.

Figure S1 shows the SDS-PAGE of Eversa and CALB, both in free and immobilized on octyl agarose. Both enzymes are quite pure, purification after immobilization is therefore negligible.

Most lipases increase its activity after immobilization on octyl agarose [27], CALB is a known exception due to the small lid that not fully isolated the active center [53], Eversa has a similar behavior.

\subsection{Modification of Octyl-Eversa with PEI}

The modification of octyl-Eversa con PEI did not have a significant effect on enzyme the standard activity assay (recovered activity versus PNPB was $105 \%$ after PEI coating). 


\subsection{Thermal Stability of the Different Lipase Biocatalysts}

The three immobilized Eversa preparations (enzyme immobilized on octyl, enzyme immobilized on octyl and then modified with PEI and the enzyme immobilized on MANAE agarose) and the free Eversa were inactivated at different $\mathrm{pH}$ values, and compared to octyl-CALB (Figure 2).

(a)

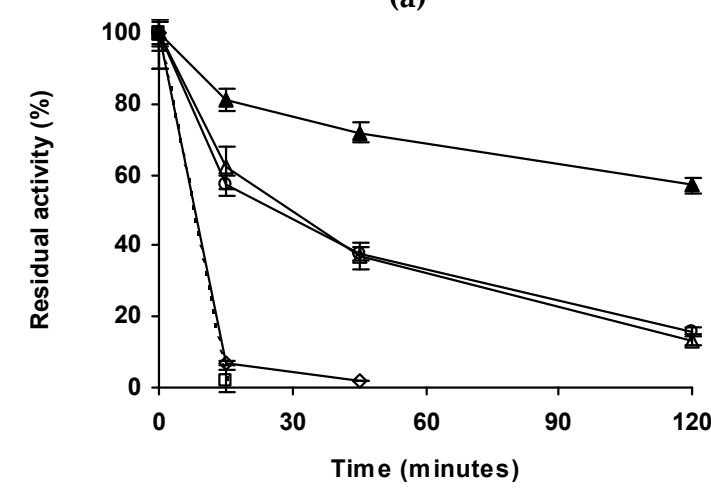

(b)

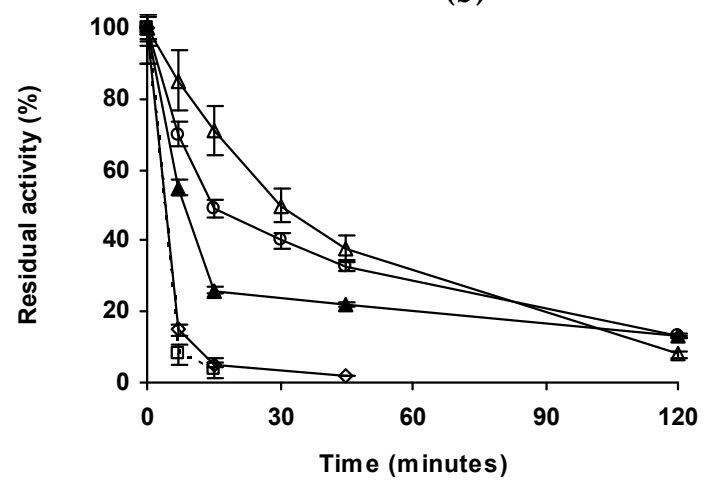

(c)

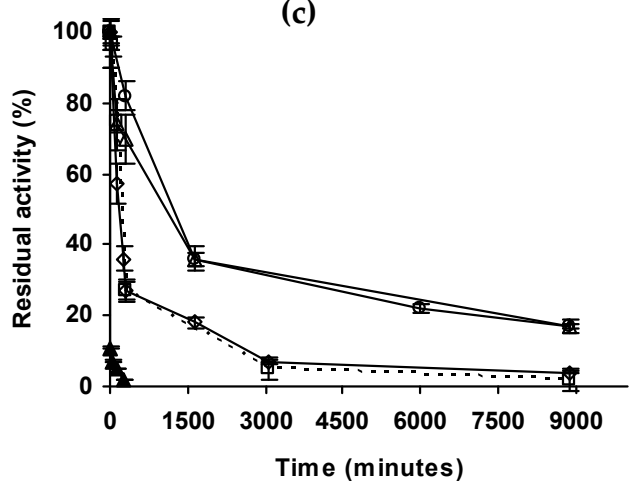

Figure 2. Thermal inactivations of different lipase preparations at pH 5 (a) and 7 (b) (both at $80{ }^{\circ} \mathrm{C}$ ) or 9 (c) $\left(65^{\circ} \mathrm{C}\right)$. Other specifications are described in methods section. Solid triangles: octyl-CALB, empty squares, dotted line, free Eversa; empty circles: Octyl-Eversa; empty triangles: Octyl-Eversa-PEI; empty rhombus: MANAE-Eversa.

At pH 5 and $80^{\circ} \mathrm{C}$ (Figure 2a), immobilized CALB is clearly the most stable preparation, retaining almost $60 \%$ of the initial activity after $2 \mathrm{~h}$ while the most stable immobilized Eversa preparation retained only around $15 \%$. Octyl-Eversa modification with PEI did not result in a significant stabilization, but both preparations were much more stable than the enzyme immobilized on MANAE or the free enzyme, both almost fully inactive in the first measure.

At $\mathrm{pH} 7$ and $80^{\circ} \mathrm{C}$ (Figure 2b), octyl-Eversa presented a stability similar to that at $\mathrm{pH} 5$, while CALB become more unstable. That way, octyl-Eversa become more stable than octyl-CALB in the first inactivation steps, but later CALB retained similar activity. The coating with PEI of octyl-Eversa also offered some stabilization in the first inactivation steps, but this effect is not so clear later. Again, free enzyme and MANAE-Eversa were almost fully inactive in the first activity determination point.

Finally, at $\mathrm{pH} 9$ (temperature was decreased to $65{ }^{\circ} \mathrm{C}$ because of the lower stability of all preparations) all Eversa preparations, including the free enzyme, became more stable than octylCALB (only $15 \%$ of residual activity after $15 \mathrm{~min}$ while the less stable Eversa preparation presented $60 \%$ after $2 \mathrm{~h}$ ). Immobilization on octyl greatly improved the stability of Eversa, while PEI coating has no effect except in the first steps of the inactivation.

The results fit the expect ones: immobilization on octyl-agarose should provide certain stabilization because the open and stabilized form of the lipase has some thermodynamic advantages $[69,70]$. That way this preparation interfacially activated versus an octyl layer is even more 
stable than multipoint covalently attached preparations [71], and that way it is expected that this can be more stable than the ionically adsorbed enzyme, where stabilization is hard to expect [72]. CALB is more stable than Eversa at $\mathrm{pH} 5$ while at $\mathrm{pH} 7$ differences are short and at $\mathrm{pH} 9$, CALB is much more unstable than Eversa. This should be associated to differences on enzymes structures.

\subsection{Inactivation of the Enzyme Preparations in Organic Solvents}

The four enzyme immobilized preparations were incubated in $90 \%$ of different solvents at $\mathrm{pH}$ 7 and $25^{\circ} \mathrm{C}$ (Figure 3). Using acetonitrile, Eversa preparations were more stable than octyl-CALB. Even there was a clear hyperactivation of the Eversa biocatalysts. For example, MANAE-Eversa after 45 days gave a $60 \%$ of hyperactivation. PEI coating of octyl-Eversa had not a positive effect. In dioxane, all preparations maintained their activity almost intact after 45 days, octyl-Eversa-PEI showing the highest activity after 45 days $(120 \%)$, shortly followed by octyl-CALB.

(a)

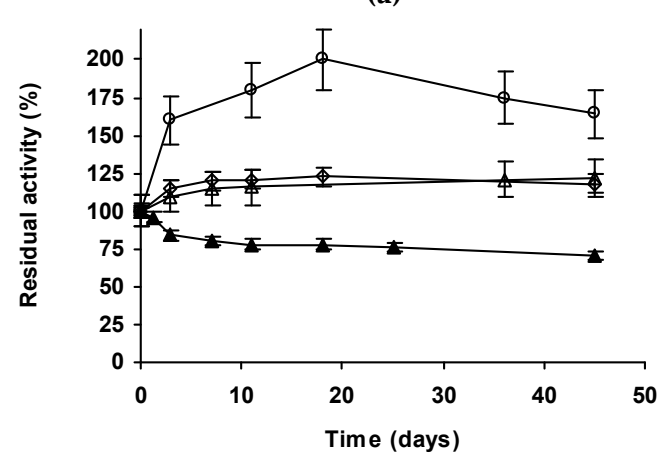

(b)

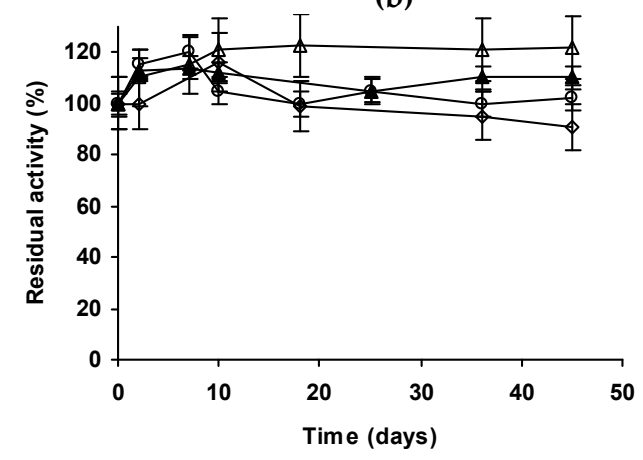

(c)

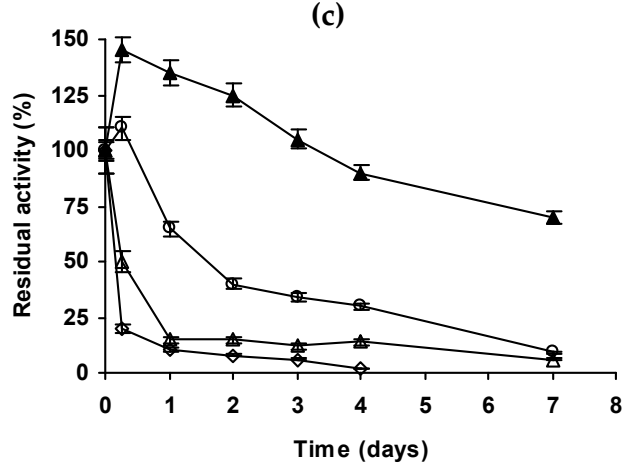

Figure 3. Inactivation in $90 \%$ of acetonitrile (a), dioxane (b) or methanol (c) of different preparations of lipases. Other specifications are described in methods section. Solid triangles: octyl-CALB, empty circles: Octyl-Eversa; empty triangles: Octyl-Eversa-PEI; empty rhombus: MANAE-Eversa.

Differences become clearer using methanol. In this case, Eversa become clearly less stable than CALB, and octyl-Eversa is the most stable preparation. In this case, MANEA- or PEI-coated preparations were much less stable than the octyl preparation.

The solvent inactivation of octyl lipase preparations is associated to the enzyme release from the support [53-56,60-62] and this will not occur in MANAE. Apparently, Eversa became so strongly adsorbed on octyl agarose that this effect was not very significant. Furthermore, the coating of the enzymes with PEI has prevented enzyme leakage and the promotion of a certain solvent partition as main functions [60-62]. Using octyl-Eversa, only using dioxane the effect is somehow positive, with acetonitrile and methanol the PEI coating effect is even negative. The presence of a cationic polymer or surface near the enzyme may stabilize incorrect structures, with negative effects on enzyme stability [73].

Considering that this enzyme has been designed to produce biodiesel [31-39], it is surprising that methanol, a substrate in this reaction, is the one with a higher negative effect on enzyme stability when 
compared to CALB. However, it may be expected that in anhydrous media the effect of methanol may be different, but this relatively poor stability of the Eversa enzyme in methanol should be considered in the biodiesel reaction design.

\subsection{Effect of $\mathrm{pH}$ on Lipase Activity versus $\mathrm{pNPB}$}

Figure 4 shows the specific activity of Eversa and CALB at different $\mathrm{pH}$ values after immobilization on different supports. First point that is evident is that all Eversa preparations were much more active than CALB versus this substrate, except MANAE and free enzyme at $\mathrm{pH} 4$.

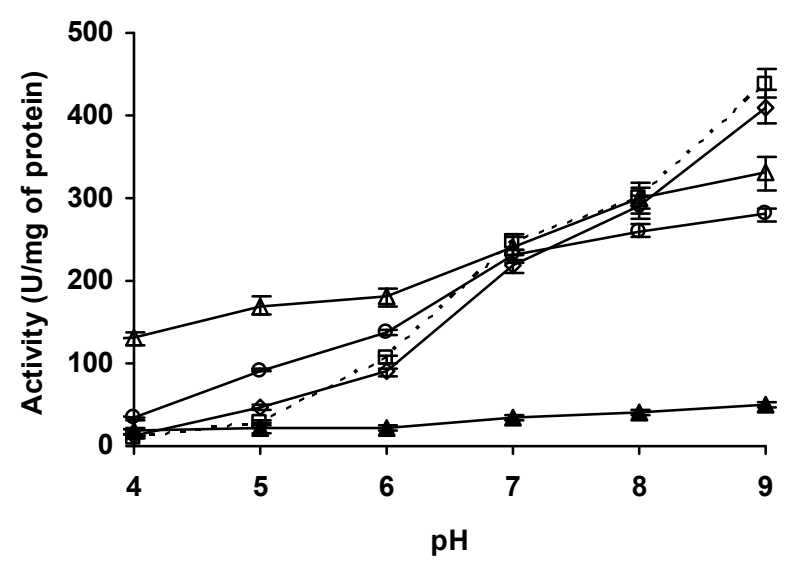

Figure 4. Effect of $\mathrm{pH}$ on the activity of different preparations of lipases versus $\mathrm{pNPB}$. Experiments were performed as described in Methods. Solid triangles: octyl-CALB, empty squares, dotted line, free Eversa; empty circles: Octyl-Eversa; empty triangles: Octyl-Eversa-PEI; empty rhombus: MANAE-Eversa.

The maximum activity was observed in all cases at the highest studied $\mathrm{pH}, \mathrm{pH}$ 9. At higher $\mathrm{pH}$ the low stability of pNPB reduces the reliability of the results. Free Eversa activity greatly increased when increasing the $\mathrm{pH}$ value, while the other preparations increase of activity is in a milder way. The largest difference when comparing the activities at $\mathrm{pH} 4$ and 9 was that between octyl coated with PEI and the free enzyme. Using octyl-Eversa- PEI the increment in activity from $\mathrm{pH} 4$ to $\mathrm{pH} 9$ is 2.5 times while for the free enzyme is 48 folds. For octyl-Eversa, it is eight-fold and for MANAE-Eversa, it is 34 .

After immobilization on octyl agarose beads, the activity almost remained unaltered at $\mathrm{pH} 7$, however greatly increased at acid $\mathrm{pH}$ value decreased the enzyme activity at alkaline $\mathrm{pH}$ value (mainly at $\mathrm{pH}$ 9). The coating of octyl-Eversa with PEI has no significant effect at $\mathrm{pH} 7$, but at all other $\mathrm{pH}$ values produced a very significant increase in activity (e.g., at $\mathrm{pH} 4$ from 33 to 130 and at $\mathrm{pH} 9$ from 240 to 330). Immobilization of Eversa on MANAE gave very low activity at $\mathrm{pH} 4$ (just over the free enzyme), at $\mathrm{pH} 7$ the activity is similar to all other preparations, but at $\mathrm{pH} 8$ and 9 it behaves more similarly to the free enzyme and gave the highest activity among the immobilized preparations.

This great difference of the effects of $\mathrm{pH}$ value on the activity of different enzyme preparations agrees with previous reports [74] and can be explained by the complexity of the lipase activity: we are measuring in some of them the activity of the active form and the percentage of molecules on the open form, the strength of the interaction between the enzyme and cationic (MANAE, PEI) or even anionic groups in the support [64], and the activity of the structure of the "open form" resulting in each condition. These results exemplify that a lipase cannot be discarded by a negative result in a specific condition, neither a positive one should be expected to be extrapolated to any other condition [74]. 


\subsection{Effect of Some Ions on the Lipase Stability}

It has been recently described that some anions, like phosphate, have a negative effect on the stability of many lipases [75]. However, these effects were only on stability at high temperature or very high buffer concentration, the activity remained unaltered when changing the buffer [75]. On the other hand, some cations (e.g., $\mathrm{Ca}^{2+}$ ) have shown to have positive effects on some lipase stabilities [76,77]. Curiously, this effect depends on the $\mathrm{pH}$ and immobilization lipase form [76,77].

Thus, we have decided to analyze the effect of $\mathrm{CaCl}_{2}$ and sodium phosphate on the stability of the different Eversa forms at pH 7, compared to octyl-CALB. Figure 5 shows the results.

(a)

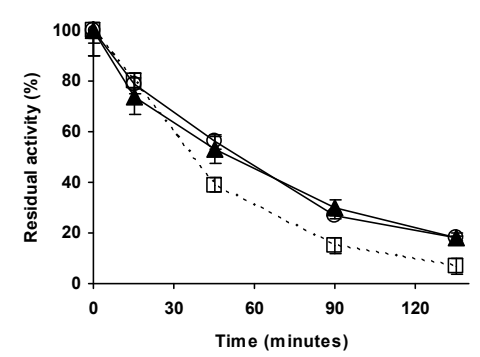

(c)

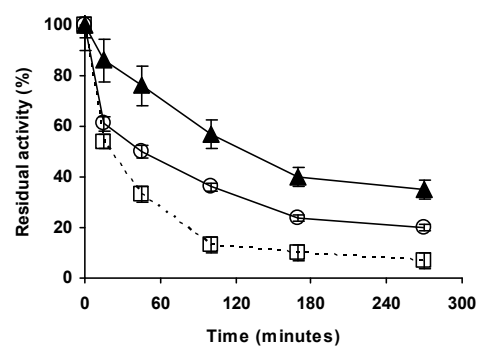

(d)

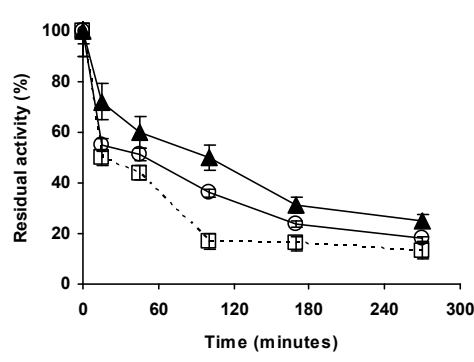

(b)

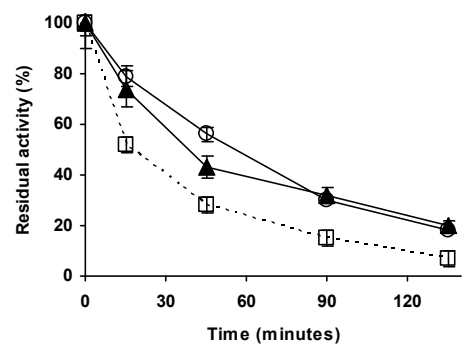

Figure 5. Effect of different ions on the stability of diverse lipase preparations an $\mathrm{pH} 7$. (a): free Eversa, $\left(72{ }^{\circ} \mathrm{C}\right) ;(\mathbf{b})$ : MANAE-Eversa $\left(72{ }^{\circ} \mathrm{C}\right) ;(\mathbf{c})$ : Octyl-Eversa $\left(78^{\circ} \mathrm{C}\right),(\mathbf{d})$ : Octyl-Eversa-PEI $\left(78^{\circ} \mathrm{C}\right)$, (e): Octyl-CALB $\left(78^{\circ} \mathrm{C}\right)$. Inactivation in $100 \mathrm{mM}$ phosphate: empty squares; inactivation in $100 \mathrm{mM}$ Tris: empty circles; inactivation in $100 \mathrm{mM}$ Tris/ $10 \mathrm{mM} \mathrm{CaCl}_{2}$ : full triangles.

Using free Eversa, the effects of the additives are not very significant. Stability in phosphate is slightly lower than in Tris, and $\mathrm{CaCl}_{2}$ has no effect. Using MANAE, the negative effect of phosphate is clear, while the effect of $\mathrm{CaCl}_{2}$ is negligible. In these cases the inactivations were performed at $72{ }^{\circ} \mathrm{C}$ because at $78{ }^{\circ} \mathrm{C}$ the inactivation was too rapid to be able to perform a reliable comparison. The other biocatalysts were inactivated at $78^{\circ} \mathrm{C}$. The situation using octyl-Eversa was different; here a positive effect of $\mathrm{CaCl}_{2}$ and a negative effect of phosphate were evident. The coating with PEI reduces the effect of the ions, but that were still clear. Octyl-CALB stability is strongly reduced in $100 \mathrm{mM}$ sodium phosphate, while the addition of $10 \mathrm{mM} \mathrm{CaCl}_{2}$ has not an evident effect (slightly higher stability in initial steps of the inactivation).

Thus, phosphate negative effect on lipase stability previously described [75] is also found using Eversa, although the effect is maximized in the octyl preparation. In any case, this effect is much lower than the one found using octyl-CALB, where phosphate produces a drastic reduction on enzyme stability, while using octyl-Eversa is reduced just by $2-3$ folds. The positive effect of $\mathrm{CaCl}_{2}$ on lipase stability is only found using octyl-Eversa, in a similar way to the previous results, [76] but it is not very significant (a 2-3 fold factors) compared to the values described with other enzymes [76].

Differences between CALB and Eversa should be based in differences in enzyme structure, in the case of MANAE and octyl-Eversa, this should be based in the fact that while in one case the open 
structure is stabilized [29], in the ion exchanged enzyme the conformational equilibrium remains. Apparently, the immobilization of Eversa on octyl agarose beads permits to maximize the positive or negative effects of the studied ions.

\subsection{Enzyme Specificity}

To investigate of the immobilization of Eversa may alter the enzyme specificity as described with other lipases [74,78], several substrates have been used. Table 1 shows the activity of different immobilized enzyme preparations versus $\mathrm{p}-\mathrm{NPB}$, R or S methyl mandelate and triacetin.

Table 1. Activity of different lipase biocatalyst versus different substrates at $\mathrm{pH} 7$ and $25^{\circ} \mathrm{C}$. Other reaction conditions are described in Methods section. Activity is given as micromoles $/ \mathrm{min} / \mathrm{mg}$ of enzyme.

\begin{tabular}{cccccc}
\hline & & \multicolumn{5}{c}{ Substrate } \\
\cline { 3 - 6 } Biocatalyst & $\mathbf{p H}$ & $\mathbf{p N P B}$ & $\begin{array}{c}\text { (R)-Methyl } \\
\text { Mandelate }\end{array}$ & $\begin{array}{c}\text { Enantiomer Activity } \\
\text { Ratio (VR/VS) }\end{array}$ & Triacetin \\
\hline & & $92 \pm 5$ & $0.0112 \pm 0.0011$ & 0.76 & $25.7 \pm 0.8$ \\
Octyl-Eversa & 7 & $230 \pm 15$ & $0.0103 \pm 0.0009$ & 0.9 & $21.6 \pm 0.6$ \\
& 9 & $280 \pm 18$ & $0.0050 \pm 0.0007$ & 0.94 & $20 \pm 0.9$ \\
\hline Octyl-Eversa & 5 & $170 \pm 10$ & $0.0083 \pm 0.0007$ & 0.64 & $28.3 \pm 1.0$ \\
treated with & 7 & $240 \pm 13$ & $0.0073 \pm 0.0004$ & 0.8 & $22.3 \pm 0.6$ \\
PEI & 9 & $330 \pm 15$ & $0.0032 \pm 0.0005$ & 0.77 & $25.0 \pm 1.2$ \\
\hline MANAE-Eversa & 7 & $220 \pm 12$ & $0.0091 \pm 0.0008$ & 0.51 & $2.95 \pm 0.08$ \\
& 9 & $410 \pm 21$ & $0.0040 \pm 0.0004$ & 0.74 & $11.0 \pm 0.3$ \\
Octyl-CALB & 5 & $21 \pm 2$ & $49.3 \pm 3.1$ & 12.0 & $9.6 \pm 1.0$ \\
& 7 & $35 \pm 2$ & $81.1 \pm 3.8$ & 8.4 & $19.9 \pm 1.6$ \\
& 9 & $50 \pm 3$ & $63.3 \pm 4.6$ & 11.3 & $10.3 \pm 0.5$ \\
\hline
\end{tabular}

As described above, Eversa is more active versus pNPB than CALB at all pHs studied. In all cases, the activity increases with $\mathrm{pH}$. Coating of octyl-Eversa with PEI increases the activity mainly at $\mathrm{pH} 5$ and 9, while it had a marginal effect at $\mathrm{pH}$ 7. MANAE-Eversa is the least active Eversa immobilized biocatalyst at $\mathrm{pH} 5$ and the most active at $\mathrm{pH} 9$.

Focusing on mandelate esters, the situation is quite different. Octyl-CALB is much more active than all Eversa preparations, preferring the $\mathrm{R}$ isomer, with a ratio in the rate of hydrolysis of the $\mathrm{R}$ isomer versus $\mathrm{S}$ enantiomer near 10 in all range of studied $\mathrm{pH}$ values. Activity is higher at $\mathrm{pH} 7$ than at $\mathrm{pH} 5$ or 9 , but the enantiomeric ratio is lower at that $\mathrm{pH}$. This enzyme is particularly active versus aromatic acyl donors. Although Eversa is hundreds fold less active; the most active Eversa preparation is octyl-Eversa. This enzyme prefers the hydrolysis of the $\mathrm{S}$ isomer, but with very low differences (maximum, a factor of less than 2). The effect of the $\mathrm{pH}$ on the enzyme activity depends on the preparation. Octyl-Eversa has the maximum activity versus methyl mandelate at $\mathrm{pH} 5$ (in opposition with the behavior using $\mathrm{pNPB}$ ), with a significant drop at $\mathrm{pH} 9$. The picture is similar after coating with PEI, although activity is $20-40 \%$ lower. MANAE-Eversa has optimal activity at $\mathrm{pH} 7$, with higher activity at $\mathrm{pH} 9$ than at $\mathrm{pH} 5$ in opposition to the octyl preparations. This preparation offered the highest (a factor of 2 at $\mathrm{pH}$ 5) and the lowest (at $\mathrm{pH} 7$, with identical activities) differences in the reaction with both enantiomers.

Using triacetin, octyl-Eversa is quite more active than octyl-CALB, mainly at alkaline and acid $\mathrm{pH}$ values. While CALB maintains a maximum activity at $\mathrm{pH} 7$ (less than $20 \mathrm{U} / \mathrm{mg}$ ) with around a 50\% decrease a $\mathrm{pH} 5$ or 9, octyl-Eversa maintains a similar level of activity (from around $25 \mathrm{U} / \mathrm{mg}$ at $\mathrm{pH} 5$ to around $21 \mathrm{U} / \mathrm{mg}$ at $\mathrm{pH} 9$ ), although the maximum activity is found at $\mathrm{pH} 5$ and the minimum at $\mathrm{pH} 9$ (similar to mandelate esters, and opposite to $\mathrm{pNPB}$ ). The coating with PEI produced a slightly increase in the activity (similar to using pNPB and opposite to the results using mandelate esters), and a change 
in the effect of the pH: now there a valley at $\mathrm{pH} 7(22.3 \mathrm{U} / \mathrm{mg})$ and at $\mathrm{pH} 5(28.3 \mathrm{U} / \mathrm{mg})$ and $\mathrm{pH}$ $9(25 \mathrm{U} / \mathrm{mg})$ the activities were higher. MANAE-Eversa have lower activity than even octyl-CALB, but it presented a clear maximum at $\mathrm{pH} 9$, at this $\mathrm{pH}$ value the activity is higher than the activity of octyl-CAB. Minimal activity is found at $\mathrm{pH} 5$.

The results above newly exemplify how immobilization of an enzyme on different supports or the physical treatment of the immobilized enzymes may greatly alter enzyme specificity and response to the changes in the medium [74,78]. Results suggested that Eversa is specially indicated to reactions where the acyl donor is aliphatic, if the acyl door is aromatic the activity greatly decrease.

Octyl-Eversa was reused seven times in hydrolysis of (R) or (S)-methyl mandelate at $\mathrm{pH} 7$ without any significant change in enzyme activity (results not shown).

\section{Materials and Methods}

\subsection{Materials}

Commercial solutions of lipase B from Candida antartica (CALB) (7.3 mg of protein per $\mathrm{mL}$ ) and lipase Eversa Transform 2.0 FG (55.4 mg of protein per $\mathrm{mL}$ ) were kindly gifted by Novozymes (Alcobendas, Spain). p-nitrophenyl butyrate (p-NPB), branched polyethyleneimine (PEI), (MW 25,000), octyl Cl-4B Sepharose beads, R- and S-methyl mandelate, triacetin, 1,4-dioxane and acetonitrile were from Sigma Aldrich (Alcobendas, Spain). Low molecular weight (LMW) calibration kit for SDS electrophoresis (14.4-97 kDa) was from GE Healthcare (Madrid, Spain), and 4\% BCL agarose beads standard from Agarose Bead Technologies (Lisbon, Portugal). All other reagents were of analytical grade. Protein concentration was determined using Bradford's method [79] with bovine serum albumin as a standard. Monoaminoethyl-N-ethyl-agarose (MANAE-agarose) was prepared as previously described $[80,81]$.

\subsection{Determination of Enzyme Activity}

Enzyme activity was measured by recording the increase in absorbance at $348 \mathrm{~nm}$ produced by the release p-nitrophenol in the hydrolysis of $0.4 \mathrm{mM} \mathrm{p}-\mathrm{NPB}$ in $25 \mathrm{mM}$ sodium phosphate buffer at $\mathrm{pH}$ 7.0 and $25{ }^{\circ} \mathrm{C}\left(\varepsilon\right.$ under these conditions is $5150 \mathrm{M}^{-1} \mathrm{~cm}^{-1}$ ), between 50 and $200 \mu \mathrm{L}$ of enzyme solution or suspension were added to $2.5 \mathrm{~mL}$ of substrate solution to commence the reaction.

\subsection{Immobilization of Enzymes}

The enzymes were insolubilized employing $1 \mathrm{mg}$ or $0.5 \mathrm{mg}$ of protein per $\mathrm{g}$ of wet support, for CALB and Eversa respectively. First, the commercial solutions of enzymes were diluted in the appropriate volume of $5 \mathrm{mM}$ sodium phosphate at $\mathrm{pH}$. Then, the support was added, $1 \mathrm{~g}$ of wet support per $10 \mathrm{~mL}$ of enzyme solution and left under mild stirring. The activities of suspension and supernatant were measured employing pNPB. After full enzyme immobilization, the suspensions were filtered and immobilized lipase biocatalysts were washed several times with distilled water.

\subsection{Coating of Immobilized Eversa by Polyethylenimine}

To $100 \mathrm{~mL}$ of $10 \%$ PEI solution at $\mathrm{pH}$ 7, $10 \mathrm{~g}$ of wet immobilized Eversa were added and left under gentle stirring for $18 \mathrm{~h}$ at $4{ }^{\circ} \mathrm{C}$. Then, the suspension was filtered and washed several times with distilled water.

\subsection{Thermal Stability}

Biocatalysts were incubated at $\mathrm{pH} \mathrm{9,7,} \mathrm{or} \mathrm{5,} \mathrm{using} 50 \mathrm{mM}$ sodium carbonate, tris or sodium acetate, respectively, at different temperatures. The activity was measured periodically using pNPB and residual activity was expressed as percentage of initial activity (initial enzyme). In some cases some additives were added (100 $\mathrm{mM}$ phosphate, $\left.10 \mathrm{mM} \mathrm{CaCl}_{2}\right)$. 


\subsection{Stability of the Lipase Biocatalysts in the Presence of Organic Co-Solvents}

Immobilized enzymes were incubated in mixtures of $90 \%(v / v)$ 1,4-dioxane, methanol or acetonitrile: $10 \%(v / v) 100 \mathrm{mM}$ Tris-HCL (pH 7) at $25^{\circ} \mathrm{C}$. Periodically, samples were withdrawn, and their residual activities were determined with $\mathrm{pNPB}$. Residual activity was expressed as percentage of initial activity.

\subsection{Effect of pH on Enzyme Activity}

To study the effect of $\mathrm{pH}$ on enzyme activity, biocatalysts were resuspended in $10 \mathrm{~mL}$ of $25 \mathrm{mM}$ Tris- $\mathrm{HCl}$ buffer $\mathrm{pH} 7.0$ and activity was measured using pNPB as described previously but using $25 \mathrm{mM}$ buffers at different $\mathrm{pH}$ (sodium acetate at $\mathrm{pH} 4-6$, sodium phosphate at $\mathrm{pH}$ 6-8 and sodium carbonate at pHs 8 and over). In some instances, the activity was measured when the enzyme was added to the buffer and $10 \mathrm{~min}$ after to ensure internal and external $\mathrm{pH}$ equilibration [74].

\subsection{SDS-PAGE Analysis}

SDS-polyacrylamide gel electrophoresis was performed on a 5\% polyacrylamide stacking gel and a $12 \%$ polyacrylamide resolving gel according to Laemmli [82] to analyze the amount of proteins that immobilize on a support. In case of free enzymes, the solutions were diluted in rupture buffer (4\% SDS and $10 \%$ mercaptoethanol) to the final concentration of $1 \mathrm{mg}$ of protein $/ \mathrm{mL}$. Using octyl-CALB, $100 \mathrm{mg}$ were re-suspended in $200 \mu \mathrm{L}$ of rupture buffer and for immobilized EVERSA $100 \mathrm{mg}$ were re-suspended in $100 \mu \mathrm{L}$ of rupture buffer. The suspensions were boiled for $8 \mathrm{~min}$ and $15 \mu \mathrm{L}$ aliquots of supernatant were loaded. The samples were run at $100 \mathrm{~V}$. Gels were stained with Coomassie brilliant blue.

\subsection{Hydrolisis of Triacetin}

Triacetin was diluted to $50 \mathrm{mM}$ in $50 \mathrm{mM}$ sodium phosphate $\mathrm{pH}$ 7.0. Biocatalyst samples between $0.15-0.45 \mathrm{~g}$ were added to $5 \mathrm{~mL}$ of triacetin solution and the reaction suspensions were kept under gentle stirring at $25{ }^{\circ} \mathrm{C}$. The concentrations of reaction products were determined by RP-HPLC (Jasco PU-2085) coupled with a UV-1575 Intelligent UV-VIS detector. A $20 \mu \mathrm{L}$ sample of proper dilution of the reaction mixture was injected and separation was performed on a Kromasil C18 column $(15 \mathrm{~cm} \times 0.46 \mathrm{~cm})$ using $15 \%$ acetonitrile-water $(v / v)$ as mobile phase at a flow rate of $1 \mathrm{~mL} / \mathrm{min}$ at $25^{\circ} \mathrm{C}$. Detection was set at $230 \mathrm{~nm}$. Retention times were $25 \mathrm{~min}$ for triacetin and $5 \mathrm{~min}$ for diacetin. Activity was determined with a maximum triacetin hydrolysis of $15 \%$ to prevent hydrolysis of 1,3 diacetin [83]. One unit of enzyme activity was determined as the amount of enzyme necessary to produce $1 \mu \mathrm{mol}$ of diacetin per minute under the conditions described above.

\subsection{Hydrolysis of Methyl Mandelate}

A total of $0.05-0.45 \mathrm{~g}$ of wet biocatalyst were added to $5 \mathrm{~mL}$ of $50 \mathrm{mM}$ R- or S-methyl mandelate in $50 \mathrm{mM}$ sodium phosphate buffer at $\mathrm{pH} 7.0$ and $25^{\circ} \mathrm{C}$. The conversion degree was determined using HPLC as in above point, employing acetonitrile/10 mM ammonium acetate $(35: 65, v / v)$ at pH 2.8 as mobile phase. Retention times were $2.4 \mathrm{~min}$ for acid and $4.2 \mathrm{~min}$ for ester.

\section{Conclusions}

Eversa properties such as stability or activity may be enhanced after a proper immobilization, although the supplier recommends use in free form. Immobilization of the enzyme on octyl agarose beads has permitted to improve the enzyme stability under a wide range of conditions. The enzyme immobilized on octyl agarose is quite sensible to the presence of phosphate (negative effect) or $\mathrm{Ca}^{2+}$ (positive effect). The enzyme is extremely stable in acetonitrile or dioxane, but not so stable in the presence of methanol. Compared to CALB, Eversa is more thermostable at $\mathrm{pH}$ 9. At $\mathrm{pH} 7$, only octyl-Eversa is slightly more stable than octyl-CALB, octyl-CALB is the most stable preparation while 
at $\mathrm{pH}$ 5. Immobilization on octyl agarose gave higher thermal stability at Eversa in all conditions than immobilization on MANAE agarose, but the coating with PEI has an unclear effect (perhaps due to the low loading of enzyme). Curiously for an enzyme designed to be used in biodiesel production, methanol presented a very negative effect on enzyme stability compared to acetonitrile or dioxane, being this effect more deleterious than for CALB. In any case, Eversa may be an interesting biocatalyst for many reactions different to biodiesel production and its immobilization on octyl agarose impairs many positive effects.

Supplementary Materials: The following are available online at http:/ / www.mdpi.com/2073-4344/8/11/511/s1, Figure S1. SDS-PAGE of different lipase preparations. Experiments were performed as described in Methods. Lane 1: Molecular markers, Lane 2: Octyl-CALB, Lane 3: CALB extract, Lane 4: Octyl-Eversa, Lane 5: Eversa extract.

Author Contributions: R.F.-L. conceived, designed the experiments, and wrote the paper; S.A.-P. and Y.L. performed the experiments and helped in writing the paper.

Funding: We gratefully recognize the support from the MINECO from Spanish Government, (project number CTQ2017-86170-R) and Colciencias (Colombia) (project number FP 44842-076-2016).

Acknowledgments: We gratefully recognize the support from the MINECO from Spanish Government, (project number CTQ2017-86170-R) and Colciencias (Colombia) (project number FP 44842-076-2016). The authors wish to thank Ramiro Martínez (Novozymes, Spain) for kindly supplying the enzymes used in this research. The suggestions of Berenguer during the writing of this paper are also gratefully recognized.

Conflicts of Interest: The authors declare no conflict of interest.

\section{References}

1. Seddigi, Z.S.; Malik, M.S.; Ahmed, S.A.; Babalghith, A.O.; Kamal, A. Lipases in asymmetric transformations: Recent advances in classical kinetic resolution and lipase-Metal combinations for dynamic processes. Coord. Chem. Rev. 2017, 348, 54-70. [CrossRef]

2. Bansode, S.R.; Rathod, V.K. An investigation of lipase catalysed sonochemical synthesis: A review. Ultrason. Sonochem. 2017, 38, 503-529. [CrossRef] [PubMed]

3. Angajala, G.; Pavan, P.; Subashini, R. Lipases: An overview of its current challenges and prospectives in the revolution of biocatalysis. Biocatal. Agric. Biotechnol. 2016, 7, 257-270. [CrossRef]

4. Kumar, A.; Dhar, K.; Kanwar, S.S.; Arora, P.K. Lipase catalysis in organic solvents: Advantages and applications. Biol. Proced. Online 2016, 18, 2. [CrossRef] [PubMed]

5. Carvalho, A.C.L.M.; Fonseca, T.S.; De Mattos, M.C.; De Oliveira, M.C.F.; De Lemos, T.L.G.; Molinari, F.; Romano, D.; Serra, I. Recent advances in lipase-mediated preparation of pharmaceuticals and their intermediates. Int. J. Mol. Sci. 2015, 16, 29682-29716. [CrossRef] [PubMed]

6. Borrelli, G.M.; Trono, D. Recombinant lipases and phospholipases and their use as biocatalysts for industrial applications. Int. J. Mol. Sci. 2015, 16, 20774-20840. [CrossRef] [PubMed]

7. de Miranda, A.S.; Miranda, L.S.M.; de Souza, R.O.M.A. Lipases: Valuable catalysts for dynamic kinetic resolutions. Biotechnol. Adv. 2015, 33, 372-393. [CrossRef] [PubMed]

8. Yang, Y.; Zhang, J.; Wu, D.; Xing, Z.; Zhou, Y.; Shi, W.; Li, Q. Chemoenzymatic synthesis of polymeric materials using lipases as catalysts: A review. Biotechnol. Adv. 2014, 32, 642-651. [CrossRef] [PubMed]

9. Zhang, J.; Shi, H.; Wu, D.; Xing, Z.; Zhang, A.; Yang, Y.; Li, Q. Recent developments in lipase-catalyzed synthesis of polymeric materials. Process Biochem. 2014, 49, 797-806. [CrossRef]

10. Stergiou, P.-Y.; Foukis, A.; Filippou, M.; Koukouritaki, M.; Parapouli, M.; Theodorou, L.G.; Hatziloukas, E.; Afendra, A.; Pandey, A.; Papamichael, E.M. Advances in lipase-catalyzed esterification reactions. Biotechnol. Adv. 2013, 31, 1846-1859. [CrossRef] [PubMed]

11. García-Verdugo, E.; Altava, B.; Burguete, M.I.; Lozano, P.; Luis, S.V. Ionic liquids and continuous flow processes: A good marriage to design sustainable processes. Green Chem. 2015, 17, 2693-2713. [CrossRef]

12. Lozano, P.; Bernal, J.M.; Garcia-Verdugo, E.; Sanchez-Gomez, G.; Vaultier, M.; Burguete, M.I.; Luis, S.V. Sponge-like ionic liquids: A new platform for green biocatalytic chemical processes. Green Chem. 2015, 17, 3706-3717. [CrossRef]

13. Lozano, P.; Nieto, S.; Serrano, J.L.; Perez, J.; Sánchez-Gomez, G.; García-Verdugo, E.; Luis, S.V. Flow biocatalytic processes in ionic liquids and supercritical fluids. Mini-Rev. Org. Chem. 2017, 14, 65-74. [CrossRef] 
14. Hama, S.; Noda, H.; Kondo, A. How lipase technology contributes to evolution of biodiesel production using multiple feedstocks. Curr. Opin. Biotechnol. 2018, 50, 57-64. [CrossRef] [PubMed]

15. Lozano, P.; Bernal, J.M.; Sánchez-Gómez, G.; López-López, G.; Vaultier, M. How to produce biodiesel easily using a green biocatalytic approach in sponge-like ionic liquids. Energy Environ. Sci. 2013, 6, 1328-1338. [CrossRef]

16. Sankaran, R.; Show, P.L.; Chang, J.-S. Biodiesel production using immobilized lipase: Feasibility and challenges. Biofuels Bioprod. Biorefin. 2016, 10, 896-916. [CrossRef]

17. Aransiola, E.F.; Ojumu, T.V.; Oyekola, O.O.; Madzimbamuto, T.F.; Ikhu-Omoregbe, D.I.O. A review of current technology for biodiesel production: State of the art. Biomass Bioenergy 2014, 61, 276-297. [CrossRef]

18. Christopher, L.P.; Kumar, H.; Zambare, V.P. Enzymatic biodiesel: Challenges and opportunities. Appl. Energy 2014, 119, 497-520. [CrossRef]

19. Brzozowski, A.M.; Derewenda, U.; Derewenda, Z.S.; Dodson, G.G.; Lawson, D.M.; Turkenburg, J.P.; Bjorkling, F.; Huge-Jensen, B.; Patkar, S.A.; Thim, L. A model for interfacial activation in lipases from the structure of a fungal lipase-inhibitor complex. Nature 1991, 351, 491-494. [CrossRef] [PubMed]

20. Jaeger, K.-E.; Dijkstra, B.W.; Reetz, M.T. Bacterial biocatalysts: Molecular biology, three-dimensional structures, and biotechnological applications of lipases. Annu. Rev. Microbiol. 1999, 53, 315-351. [CrossRef] [PubMed]

21. Grochulski, P.; Li, Y.; Schrag, J.D.; Bouthillier, F.; Smith, P.; Harrison, D.; Rubin, B.; Cygler, M. Insights into interfacial activation from an open structure of Candida rugosa lipase. J. Biol. Chem. 1993, 268, 12843-12847. [PubMed]

22. Verger, R. 'Interfacial activation' of lipases: Facts and artifacts. Trends Biotechnol. 1997, 15, 32-38. [CrossRef]

23. Wang, P.; He, J.; Sun, Y.; Reynolds, M.; Zhang, L.; Han, S.; Liang, S.; Sui, H.; Lin, Y. Display of fungal hydrophobin on the Pichia pastoris cell surface and its influence on Candida antarctica lipase B. Appl. Microbiol. Biotechnol. 2016, 100, 5883-5895. [CrossRef] [PubMed]

24. Palomo, J.M.; Peñas, M.M.; Fernández-Lorente, G.; Mateo, C.; Pisabarro, A.G.; Fernández-Lafuente, R.; Ramírez, L.; Guisán, J.M. Solid-phase handling of hydrophobins: Immobilized hydrophobins as a new tool to study lipases. Biomacromolecules 2003, 4, 204-210. [CrossRef] [PubMed]

25. Palomo, J.M.; Ortiz, C.; Fuentes, M.; Fernandez-Lorente, G.; Guisan, J.M.; Fernandez-Lafuente, R. Use of immobilized lipases for lipase purification via specific lipase-lipase interactions. J. Chromatogr. A 2004, 1038, 267-273. [CrossRef] [PubMed]

26. Palomo, J.M.; Ortiz, C.; Fernández-Lorente, G.; Fuentes, M.; Guisán, J.M.; Fernández-Lafuente, R. Lipase-lipase interactions as a new tool to immobilize and modulate the lipase properties. Enzyme Microb. Technol. 2005, 36, 447-454. [CrossRef]

27. Fernandez-Lafuente, R.; Armisén, P.; Sabuquillo, P.; Fernández-Lorente, G.; Guisán, J.M. Immobilization of lipases by selective adsorption on hydrophobic supports. Chem. Phys. Lipids 1998, 93, 185-197. [CrossRef]

28. Palomo, J.M.; Muoz, G.; Fernández-Lorente, G.; Mateo, C.; Fernández-Lafuente, R.; Guisán, J.M. Interfacial adsorption of lipases on very hydrophobic support (octadecyl-Sepabeads): Immobilization, hyperactivation and stabilization of the open form of lipases. J. Mol. Catal. B Enzym. 2002, 19, 279-286. [CrossRef]

29. Manoel, E.A.; dos Santos, J.C.S.; Freire, D.M.G.; Rueda, N.; Fernandez-Lafuente, R. Immobilization of lipases on hydrophobic supports involves the open form of the enzyme. Enzyme Microb. Technol. 2015, 71, 53-57. [CrossRef] [PubMed]

30. New Enzyme Technology Converts Waste Oils into Biodiesel. Available online: https:/ /www.novozymes. com/es/news/news-archive/2014/12/new-enzyme-technology-converts-waste-oil-into-biodiesel (accessed on 11 October 2018).

31. Adewale, P.; Vithanage, L.N.; Christopher, L. Optimization of enzyme-catalyzed biodiesel production from crude tall oil using Taguchi method. Energy Convers. Manag. 2017, 154, 81-91. [CrossRef]

32. Andrade, T.A.; Errico, M.; Christensen, K.V. Transesterification of castor oil catalyzed by liquid enzymes: Optimization of reaction conditions. Comput. Aided Chem. Eng. 2017, 40, 2863-2868. [CrossRef]

33. Andrade, T.A.; Errico, M.; Christensen, K.V. Evaluation of Reaction Mechanisms and Kinetic Parameters for the Transesterification of Castor Oil by Liquid Enzymes. Ind. Eng. Chem. Res. 2017, 56, 9478-9488. [CrossRef]

34. Nguyen, H.C.; Huong, D.T.M.; Juan, H.-Y.; Su, C.-H.; Chien, C.-C. Liquid lipase-catalyzed esterification of oleic acid with methanol for biodiesel production in the presence of superabsorbent polymer: Optimization by using response surface methodology. Energies 2018, 11, 1085. [CrossRef] 
35. He, Y.; Li, J.; Kodali, S.; Balle, T.; Chen, B.; Guo, Z. Liquid lipases for enzymatic concentration of n-3 polyunsaturated fatty acids in monoacylglycerols via ethanolysis: Catalytic specificity and parameterization. Bioresour. Technol. 2017, 224, 445-456. [CrossRef] [PubMed]

36. Andrade, T.A.; Errico, M.; Christensen, K.V. Castor oil transesterification catalysed by liquid enzymes: Feasibility of reuse under various reaction conditions. Chem. Eng. Trans. 2017, 57, 913-918. [CrossRef]

37. Uliana, N.R.; Polloni, A.; Paliga, M.; Veneral, J.G.; Quadri, M.B.; Oliveira, J.V. Acidity reduction of enzymatic biodiesel using alkaline washing. Renew. Energy 2017, 113, 393-396. [CrossRef]

38. Remonatto, D.; Santin, C.M.T.; De Oliveira, D.; Di Luccio, M.; De Oliveira, J.V. FAME Production from waste oils through commercial soluble lipase Eversa ${ }^{\circledR}$ catalysis. Ind. Biotechnol. 2016, 12, 254-262. [CrossRef]

39. Remonatto, D.; de Oliveira, J.V.; Manuel Guisan, J.; de Oliveira, D.; Ninow, J.; Fernandez-Lorente, G. Production of FAME and FAEE via alcoholysis of sunflower oil by Eversa lipases immobilized on hydrophobic supports. Appl. Biochem. Biotechnol. 2018, 185, 705-716. [CrossRef] [PubMed]

40. Barbosa, O.; Ortiz, C.; Berenguer-Murcia, Á.; Torres, R.; Rodrigues, R.C.; Fernandez-Lafuente, R. Strategies for the one-step immobilization-purification of enzymes as industrial biocatalysts. Biotechnol. Adv. 2015, 33, 435-456. [CrossRef] [PubMed]

41. Garcia-Galan, C.; Berenguer-Murcia, A.; Fernandez-Lafuente, R.; Rodrigues, R.C. Potential of different enzyme immobilization strategies to improve enzyme performance. Adv. Synth. Catal. 2011, 353, $2885-2904$. [CrossRef]

42. Mateo, C.; Palomo, J.M.; Fernandez-Lorente, G.; Guisan, J.M.; Fernandez-Lafuente, R. Improvement of enzyme activity, stability and selectivity via immobilization techniques. Enzyme Microb. Technol. 2007, 40, 1451-1463. [CrossRef]

43. Bilal, M.; Rasheed, T.; Zhao, Y.; Iqbal, H.M.N.; Cui, J. "Smart” chemistry and its application in peroxidase immobilization using different support materials. Int. J. Biol. Macromol. 2018, 119, 278-290. [CrossRef] [PubMed]

44. Guzik, U.; Hupert-Kocurek, K.; Wojcieszynska, D. Immobilization as a strategy for improving enzyme properties- Application to oxidoreductases. Molecules 2014, 19, 8995-9018. [CrossRef] [PubMed]

45. Di Cosimo, R.; Mc Auliffe, J.; Poulose, A.J.; Bohlmann, G. Industrial use of immobilized enzymes. Chem. Soc. Rev. 2013, 42, 6437-6474. [CrossRef] [PubMed]

46. Cantone, S.; Ferrario, V.; Corici, L.; Ebert, C.; Fattor, D.; Spizzo, P.; Gardossi, L. Efficient immobilisation of industrial biocatalysts: Criteria and constraints for the selection of organic polymeric carriers and immobilisation methods. Chem. Soc. Rev. 2013, 42, 6262-6276. [CrossRef] [PubMed]

47. Sheldon, R.A.; van Pelt, S. Enzyme immobilisation in biocatalysis: Why, what and how. Chem. Soc. Rev. 2013, 42, 6223-6235. [CrossRef] [PubMed]

48. Friedrich, J.L.R.; Peña, F.P.; Garcia-Galan, C.; Fernandez-Lafuente, R.; Ayub, M.A.Z.; Rodrigues, R.C. Effect of immobilization protocol on optimal conditions of ethyl butyrate synthesis catalyzed by lipase B from Candida antarctica. J. Chem. Technol. Biotechnol. 2013, 88, 1089-1095. [CrossRef]

49. Séverac, E.; Galy, O.; Turon, F.; Pantel, C.A.; Condoret, J.-S.; Monsan, P.; Marty, A. Selection of CalB immobilization method to be used in continuous oil transesterification: Analysis of the economical impact. Enzyme Microb. Technol. 2011, 48, 61-70. [CrossRef] [PubMed]

50. Tacias-Pascacio, V.G.; Virgen-Ortiz, J.J.; Jimenez -Perez, M.; Yates, M.; Torrestiana-Sanchez, B.; Rosales-Quintero, A.; Fernandez-Lafuente, R. Evaluation of different lipase biocatalysts in the production of biodiesel from used cooking oil: Critical role of the immobilization support. Fuel 2017, 200, 1-10. [CrossRef]

51. Poppe, J.K.; Matte, C.R.; Do Carmo Ruaro Peralba, M.; Fernandez-Lafuente, R.; Rodrigues, R.C.; Ayub, M.A.Z. Optimization of ethyl ester production from olive and palm oils using mixtures of immobilized lipases. Appl. Catal. A-Gen. 2015, 490, 50-56. [CrossRef]

52. Alves, J.S.; Vieira, N.S.; Cunha, A.S.; Silva, A.M.; Záchia Ayub, M.A.; Fernandez-Lafuente, R.; Rodrigues, R.C. Combi-lipase for heterogeneous substrates: A new approach for hydrolysis of soybean oil using mixtures of biocatalysts. RSC Adv. 2014, 4, 6863-6868. [CrossRef]

53. Rueda, N.; Dos Santos, J.C.S.; Torres, R.; Ortiz, C.; Barbosa, O.; Fernandez-Lafuente, R. Improved performance of lipases immobilized on heterofunctional octyl-glyoxyl agarose beads. RSC Adv. 2015, 5, 11212-11222. [CrossRef] 
54. Virgen-Ortíz, J.J.; Tacias-Pascacio, V.G.; Hirata, D.B.; Torrestiana-Sanchez, B.; Rosales-Quintero, A.; Fernandez-Lafuente, R. Relevance of substrates and products on the desorption of lipases physically adsorbed on hydrophobic supports. Enzyme Microb. Technol. 2017, 96, 30-35. [CrossRef] [PubMed]

55. Hirata, D.B.; Albuquerque, T.L.; Rueda, N.; Virgen-Ortíz, J.J.; Tacias-Pascacio, V.G.; Fernandez-Lafuente, R. Evaluation of different immobilized lipases in transesterification reactions using tributyrin: Advantages of the heterofunctional octyl agarose beads. J. Mol. Catal. B Enzym. 2016, 133, 117-123. [CrossRef]

56. Hirata, D.B.; Albuquerque, T.L.; Rueda, N.; Sánchez-Montero, J.M.; Garcia-Verdugo, E.; Porcar, R.; Fernandez-Lafuente, R. Advantages of heterofunctional octyl supports: Production of 1,2-dibutyrin by specific and selective hydrolysis of tributyrin catalyzed by immobilized lipases. ChemistrySelect 2016, 1, 3259-3270. [CrossRef]

57. Bernal, C.; Illanes, A.; Wilson, L. Heterofunctional hydrophilic-hydrophobic porous silica as support for multipoint covalent immobilization of lipases: Application to lactulose palmitate synthesis. Langmuir 2014, 30, 3557-3566. [CrossRef] [PubMed]

58. Guajardo, N.; Bernal, C.; Wilson, L.; Cabrera, Z. Selectivity of R- $\alpha$-monobenzoate glycerol synthesis catalyzed by Candida antarctica lipase B immobilized on heterofunctional supports. Process Biochem. 2015, 50, 1870-1877. [CrossRef]

59. Fernandez-Lorente, G.; Filice, M.; Lopez-Vela, D.; Pizarro, C.; Wilson, L.; Betancor, L.; Avila, Y.; Guisan, J.M. Cross-linking of lipases adsorbed on hydrophobic supports: Highly selective hydrolysis of fish oil catalyzed by RML. JAOCS. J. Am. Oil. Chem. Soc. 2011, 88, 801-807. [CrossRef]

60. Fernandez-Lopez, L.; Pedrero, S.G.; Lopez-Carrobles, N.; Virgen-Ortíz, J.J.; Gorines, B.C.; Otero, C.; Fernandez-Lafuente, R. Physical crosslinking of lipase from Rhizomucor miehei immobilized on octyl agarose via coating with ionic polymers: Avoiding enzyme release from the support. Process Biochem. 2017, 54, 81-88. [CrossRef]

61. Fernandez-Lopez, L.; Virgen-Ortíz, J.J.; Pedrero, S.G.; Lopez-Carrobles, N.; Gorines, B.C.; Otero, C.; Fernandez-Lafuente, R. Optimization of the coating of octyl-CALB with ionic polymers to improve stability and decrease enzyme leakage. Biocatal. Biotransf. 2018, 36, 47-56. [CrossRef]

62. Zaak, H.; Fernandez-Lopez, L.; Otero, C.; Sassi, M.; Fernandez-Lafuente, R. Improved stability of immobilized lipases via modification with polyethylenimine and glutaraldehyde. Enzyme Microb. Technol. 2017, 106, 67-74. [CrossRef] [PubMed]

63. Virgen-Ortíz, J.J.; Dos Santos, J.C.S.; Berenguer-Murcia, Á.; Barbosa, O.; Rodrigues, R.C.; Fernandez-Lafuente, R. Polyethylenimine: A very useful ionic polymer in the design of immobilized enzyme biocatalysts. J. Mater. Chem. B 2017, 5, 7461-7490. [CrossRef]

64. Peirce, S.; Virgen-Ortíz, J.J.; Tacias-Pascacio, V.G.; Rueda, N.; Bartolome-Cabrero, R.; Fernandez-Lopez, L.; Russo, M.E.; Marzocchella, A.; Fernandez-Lafuente, R. Development of simple protocols to solve the problems of enzyme coimmobilization. Application to coimmobilize a lipase and a $\beta$-galactosidase. RSC Adv. 2016, 6, 61707-61715. [CrossRef]

65. Zaak, H.; Kornecki, J.F.; Siar, E.-H.; Fernandez-Lopez, L.; Corberán, V.C.; Sassi, M.; Fernandez-Lafuente, R. Coimmobilization of enzymes in bilayers using PEI as a glue to reuse the most stable enzyme: Preventing pei release during inactivated enzyme desorption. Process Biochem. 2017, 61, 95-101. [CrossRef]

66. Velasco-Lozano, S.; Benítez-Mateos, A.I.; López-Gallego, F. Co-immobilized phosphorylated cofactors and enzymes as self-sufficient heterogeneous biocatalysts for chemical processes. Angew. Chem. Int. Ed. 2017, 56, 771-775. [CrossRef] [PubMed]

67. Gotor-Fernández, V.; Busto, E.; Gotor, V. Candida antarctica lipase B: An ideal biocatalyst for the preparation of nitrogenated organic compounds. Adv. Synth. Catal. 2006, 348, 797-812. [CrossRef]

68. Anderson, E.M.; Larsson, K.M.; Kirk, O. One biocatalyst-Many applications: The use of Candida antarctica B-lipase in organic synthesis. Biocatal. Biotransf. 1998, 16, 181-204. [CrossRef]

69. Jaeger, K.-E.; Ransac, S.; Koch, H.B.; Ferrato, F.; Dijkstra, B.W. Topological characterization and modeling of the 3D structure of lipase from Pseudomonas aeruginosa. FEBS Lett. 1993, 332, 143-149. [CrossRef]

70. Cygler, M.; Schrag, J.D. Structure and conformational flexibility of Candida rugosa lipase. Biochim. Biophys. Acta Mol. Cell Biol. Lipids 1999, 1441, 205-214. [CrossRef]

71. Dos Santos, J.C.S.; Rueda, N.; Torres, R.; Barbosa, O.; Gonçalves, L.R.B.; Fernandez-Lafuente, R. Evaluation of divinylsulfone activated agarose to immobilize lipases and to tune their catalytic properties. Process Biochem. 2015, 50, 918-927. [CrossRef] 
72. Santos, J.C.S.D.; Barbosa, O.; Ortiz, C.; Berenguer-Murcia, A.; Rodrigues, R.C.; Fernandez-Lafuente, R. Importance of the support properties for immobilization or purification of enzymes. ChemCatChem 2015, 7, 2413-2432. [CrossRef]

73. Virgen-Ortíz, J.J.; Peirce, S.; Tacias-Pascacio, V.G.; Cortes-Corberan, V.; Marzocchella, A.; Russo, M.E.; Fernandez-Lafuente, R. Reuse of anion exchangers as supports for enzyme immobilization: Reinforcement of the enzyme-support multiinteraction after enzyme inactivation. Process Biochem. 2016, 51, 1391-1396. [CrossRef]

74. Rodrigues, R.C.; Ortiz, C.; Berenguer-Murcia, A.; Torres, R.; Fernández-Lafuente, R. Modifying enzyme activity and selectivity by immobilization. Chem. Soc. Rev. 2013, 42, 6290-6307. [CrossRef] [PubMed]

75. Zaak, H.; Fernandez-Lopez, L.; Velasco-Lozano, S.; Alcaraz-Fructuoso, M.T.; Sassi, M.; Lopez-Gallego, F.; Fernandez-Lafuente, R. Effect of high salt concentrations on the stability of immobilized lipases: Dramatic deleterious effects of phosphate anions. Process Biochem. 2017, 62, 128-134. [CrossRef]

76. Fernandez-Lopez, L.; Bartolome-Cabrero, R.; Rodriguez, M.D.; Dos Santos, C.S.; Rueda, N.; Fernandez-Lafuente, R. Stabilizing effects of cations on lipases depend on the immobilization protocol. RSC Adv. 2015, 5, 83868-83875. [CrossRef]

77. Fernandez-Lopez, L.; Rueda, N.; Bartolome-Cabrero, R.; Rodriguez, M.D.; Albuquerque, T.L.; Dos Santos, J.C.S.; Barbosa, O.; Fernandez-Lafuente, R. Improved immobilization and stabilization of lipase from Rhizomucor miehei on octyl-glyoxyl agarose beads by using $\mathrm{CaCl}$. Process Biochem. 2016, 51, 48-52. [CrossRef]

78. Palomo, J.M.; Fernandez-Lorente, G.; Mateo, C.; Ortiz, C.; Fernandez-Lafuente, R.; Guisan, J.M. Modulation of the enantioselectivity of lipases via controlled immobilization and medium engineering: Hydrolytic resolution of mandelic acid esters. Enzyme Microb. Technol. 2002, 31, 775-783. [CrossRef]

79. Bradford, M.M. A rapid and sensitive method for the quantitation of microgram quantities of protein utilizing the principle of protein-dye binding. Anal. Biochem. 1976, 72, 248-254. [CrossRef]

80. Fernandez-Lafuente, R.; Rosell, C.M.; Rodriguez, V.; Santana, C.; Soler, G.; Bastida, A.; Guisán, J.M. Preparation of activated supports containing low $\mathrm{pK}$ amino groups. A new tool for protein immobilization via the carboxyl coupling method. Enzyme Microb. Technol. 1993, 15, 546-550. [CrossRef]

81. Pereira, M.G.; Facchini, F.D.A.; Filó, L.E.C.; Polizeli, A.M.; Vici, A.C.; Jorge, J.A.; Fernandez-Lorente, G.; Pessela, B.C.; Guisan, J.M.; Polizeli, M.L.T.M. Immobilized lipase from Hypocrea pseudokoningii on hydrophobic and ionic supports: Determination of thermal and organic solvent stabilities for applications in the oleochemical industry. Process Biochem. 2015, 50, 561-570. [CrossRef]

82. Laemmli, U.K. Cleavage of structural proteins during the assembly of the head of bacteriophage T4. Nature 1970, 227, 680-685. [CrossRef] [PubMed]

83. Hernandez, K.; Garcia-Verdugo, E.; Porcar, R.; Fernandez-Lafuente, R. Hydrolysis of triacetin catalyzed by immobilized lipases: Effect of the immobilization protocol and experimental conditions on diacetin yield. Enzyme Microb. Technol. 2011, 48, 510-517. [CrossRef] [PubMed] 